\title{
A Monoclonal Antibody Detecting an Antigen Shared by Neural and Granulocytic Cells
}

\author{
J. T. KEMSHEAD, ${ }^{(25)}$ D. BICKNELL, AND M. F. GREAVES \\ Membrane Immunology Laboratory, Imperial Cancer Research Fund, Lincoln's Inn Fields, London, England \\ [J. T. K., D. B., M. F. G.], and Department of Medical Oncology, St. Bartholomew's Hospital, West Smithfield, \\ London, England [J. T. K.]
}

\begin{abstract}
Summary
A monoclonal antibody, MI/N1, is described that reacts predominantly with fresh neuroblastoma tissue, human neuroblastoma cell lines, and cells of the myeloid lineage. Investigation of the binding of this antibody to four different neuroblastoma cell lines showed CHP 100 bound approximately 4 times more antibody than CHP 126. Only 30\% of the cells in the line CHP 100 bound $\mathrm{MI} / \mathrm{N1}$ as determined by indirect immunofluorescence. Thus, both quantitative and qualitative differences in the expression of antigen recognised by $\mathrm{MI} / \mathrm{N1}$ are detected on human neuroblastoma cell lines. Inasmuch as only five of eight marrow aspirates heavily infiltrated with neuroblasts bound the monoclonal, this also suggests a heterogeneity in antigenic expression on fresh tumour cells. Absorption studies indicate that the antigen recognised by $\mathrm{MI} / \mathrm{Nl}$ is present on human foetal brain and adult human cerebellum. At a dilution of $1 / 750$, equal volumes of foetal brain and adult cerebellum absorbed out 30 and $60 \%$ of the reactivity to the human neuroblastoma cell line CHP 100. No reactivity was found towards murine neuroblastoma cells or rat brain.

Expression of antigen on cells in the myeloid lineage appears dependent upon their stage of maturation, increasing as cells mature to neutrophils and eosinophils.

It is suggested that the quantitative and qualitative differences seen in the expression of antigen on neuroblastoma cells may relate to their being blocked at different stages of differentiation.
\end{abstract}

Although some childhood malignancies of neural crest origin have shown improvements in clinical response in the last decade this has not been the case for neuroblastoma $(6,17)$. Despite the development of new chemotherapeutic regimes, prognosis still remains poor in this malignancy, especially in older children (over the age of 2 years) presenting with stage 3 or 4 of the disease (2, 4).

An immunologic approach has been sought to aid the early detection of metastatic spread of neuroblastoma, especially with reference to infiltration of the bone marrow $(1,3)$. Present methods of identifying tumour infiltration rely on an histologic analysis of biopsy samples where it is often difficult to definitively distinguish low levels of neuroblasts from normal haematopoietic blast cells present in the bone marrow (12). Antibodies specific for neuroblastoma tumour cells or neural tissue would serve clearly to identify tumour cells and might in addition have a use in autologous bone marrow transplantation, i.e., for removing residual tumour cells (23).

In the search for such monospecific reagents, somatic cell hybridisation has been used to produce monoclonal antibodies $(18,19)$. In this paper, we describe a new monoclonal antibody, raised against a neuroblastoma cell line, which reacts with neural tissue and at least one haematopoietic cell type.

\section{MATERIALS AND METHODS}

\author{
MICE AND IMMUNISATIONS
}

Female BALB/c mice, 2 to 3 months old, reared under specific pathogen-free conditions were immunised by intraperitoneal (IP) injection with $10^{7}$ human neuroblastoma cells (line CHP 100) in complete Freund's adjuvant. Thirty days later, a secondary injection of $10^{7}$ cells was given IP without adjuvant, and the spleens from these mice removed 5 days later for cell fusion (14).

\section{CELL HYBRIDISATION AND ASSAY FOR ANTIBODY SECRETION}

Spleen cells were fused with the mouse myeloma cell line P3X63-Ag8-653 (11) using polyethylene glycol 1500, following the method of Köhler and Milstein $(18,19)$. Cells were plated out in $1.0 \mathrm{ml}$ aliquots at $2 \times 10^{6} \mathrm{cells} / \mathrm{ml}$ in the presence of $5 \times 10^{4}$ peritoneal exudate cells from BALB/c mice. After the selection for hybrids in medium containing hypoxanthine, aminopterin, and thymidine (20), supernatants from hybrid cultures were assayed for antibody binding to the human neuroblastoma line CHP 100 (22).

Supernatants were incubated with $2 \times 10^{5}$ cells for $30 \mathrm{~min}$ at room temperature in Cooke microtitre plates that were prewashed in phosphate-buffered saline (PBS) containing $1 \%$ foetal calf serum (FCS). After washing 3 times with PBS/1\% FCS, the cells were incubated for $30 \mathrm{~min}$ at room temperature with $30 \mathrm{ng}$ of affinity purified ${ }^{125} \mathrm{I}$-goat anti-mouse immunoglobulin $(\mathrm{Ig})(7 \mu \mathrm{Ci}$

${ }^{125} \mathrm{I} / \mu \mathrm{g}$ protein). Iodinated antibody binding to a pellet of cells was determined in a LKB 1280 Ultragamma counter. All assays were in duplicate, and supernatants giving at least 2 times background were taken as positive. Cells from such wells were cloned 3 times by limiting dilution in the presence of $5 \times 10^{4}$ peritoneal exudate cells.

For ascites preparation, mice were primed with $200 \mu \mathrm{l}$ of Pristaine oil 2 wk before immunisation with $5 \times 10^{6}$ hybrid cells (15). Ascites fluid was collected 2 to 3 wk later and ultracentrifuged before use.

\section{CELL LINES}

Human neuroblastoma cell lines CHP 100, 212, 134 and 126 (obtained from Dr. Schlessinger, Children's Hospital, Philadelphia) which were grown at $37^{\circ} \mathrm{C}$ in a $6 \% \mathrm{CO}_{2}$ incubator using Roswell Park Memorial Institute 1640 medium supplemented with $10 \% \mathrm{FCS}, 2 \mathrm{mM}$ glutamine, penicillin $(100 \mathrm{IU} / \mathrm{ml})$, and streptomycin $(100 \mu \mathrm{g} / \mathrm{ml})$. When approaching confluency, cells were split $1: 3 / 1: 5$ using tryspin/ versene to remove adherent cells from the dishes when necessary.

Leukaemic cell lines growing in suspension culture were grown at $37^{\circ} \mathrm{C}$ in $10 \% \mathrm{CO}_{2}$ using Roswell Park Memorial Institute 1640 medium, 10\% FCS, and the above supplements. 


\section{IMMUNOFLUORESCENCE}

Indirect immunofluorescence using fluorescein-conjugated $\mathrm{F}\left(\mathrm{ab}^{\prime}\right)_{2}$ goat anti-mouse $\mathrm{F}\left(\mathrm{ab}^{\prime}\right)_{2}$ was carried out as described in Greaves and Janossy (7). Cells were examined using a Zeiss fluorescent microscope with incident illumination and by flow cytofluorimetry using a fluorescence activated cell sorter (FACSI, Becton Dickinson, Mountain View, CA) (9).

\section{PREPARATION OF FRESH NEURAL TISSUE}

Within $24 \mathrm{hr}$ of death, either foetal or adult brain suspensions were washed 3 times in PBS/1\% FCS and centrifuged in a Beckmann microfuge $(5 \mathrm{~min}$ at $10,000 \times \mathrm{g})$. Two hundred $\mu 1$ of an ascites preparation of antibody were added to the pelleted neural material (200 $\mu$ l packed volume), and the mixture was incubated at $4^{\circ} \mathrm{C}$ for $60 \mathrm{~min}$.

After this period, the tubes were centrifuged at $10,000 \times g$ for $5 \mathrm{~min}$, and an assay for residual antibody in the supernatant was undertaken using CHP 100 cells and ${ }^{125}$ I-goat anti-mouse.

\section{RESULTS}

\section{CHARACTERISATION OF ANTIBODY}

After fusion, cells were plated out into 50 wells $\left(2 \times 10^{6} /\right.$ well $)$ and left for 14 days in the presence of medium containing hypoxanthine, aminopterin, and thymidine. At least one hybrid colony and often many more were seen in each well. Over the subsequent $2 \mathrm{wk}$, supernatants from the cultures were assayed for antibodies to the human neuroblastoma cell line CHP 100 by an indirect binding assay using ${ }^{125}$ I-labeled goat anti-mouse immunoglobulin. In eight of 50 supernatants, antibodies to human neuroblastoma cells were detected, and cells from each of these cultures were cloned three times by limiting dilution to ensure monoclonality. One of these eight cell lines was found to secrete antibodies with restricted binding activity and was investigated further (Table 1).

\section{REACTIVITY OF MI/NI WITH NEUROBLASTOMA CELL LINES}

To determine if $\mathrm{MI} / \mathrm{Nl}$ could be used as a general marker for human neuroblastoma cells, several lines were assayed for their ability to bind the antibody. Under conditions where the ${ }^{125} \mathrm{I}$-anti-

Table 1. Binding of $M I / N I$ to neural and haemopoietic cell lines ${ }^{1}$

\begin{tabular}{|c|c|c|c|}
\hline \multirow[b]{2}{*}{ Line } & \multirow[b]{2}{*}{ Origin } & \multicolumn{2}{|c|}{$\begin{array}{l}\text { Binding above back- } \\
\text { ground }\end{array}$} \\
\hline & & $\begin{array}{c}\text { Culture } \\
\text { superna- } \\
\text { tant }\end{array}$ & Ascites \\
\hline CHP 100 & Neuroblastoma & $\times 6$ & $\times 10.3$ \\
\hline UCH-P45 & Astrocytoma & & \\
\hline NALM 1 & $\begin{array}{l}\mathrm{Ph}^{1+} \text { pre-B common acute } \\
\text { lymphoblastic leukae- } \\
\text { mia (cALL) }\end{array}$ & & \\
\hline KM3 & Non-B, non-T cALL & & \\
\hline DAUDI & B lymphoma lacking HLA & & \\
\hline RAJI & B lymphoma & & \\
\hline HPB-TALL & T-ALL & $\times 2.8$ & $\times 3.6$ \\
\hline HL 60 & Promyelocytic leukaemia & $\times 8.6$ & $\times 19.3$ \\
\hline K562 & $\mathrm{Ph}^{1+}$ myeloid leukaemia & & \\
\hline
\end{tabular}

${ }^{1}$ Two $\times 10^{5}$ cells of each line were incubated with either (1) undiluted culture supernatant or (2) an ascites preparation of the antibody diluted $1 / 250$, followed by $100,000 \mathrm{cpm}$ of ${ }^{125} \mathrm{I}$-goat anti-mouse $\mathrm{Ig}$ as described in "Materials and Methods." The ratio of counts bound to the cell line over a background (obtained by incubating cells with ${ }^{125}$ I-goat anti-mouse Ig) is given above. All backgrounds were in the range of 200 to $350 \mathrm{cpm}$.

${ }^{2} \mathrm{Ph}^{1+}$, Philadelphia chromosome. mouse Ig was in excess, considerable variation in the binding of the monoclonal to different neuroblastoma cell lines was detected (Fig. 1). Maximal binding was found against the line CHP 100, and the shape of the titration curve indicates that to a dilution of $1 / 1$ co the monoclonal antibody was saturating all antigenic sites (Fig. 1). Only approximately 20 to $25 \%$ of the activity to CHP 100 was found upon titration of $\mathrm{MI} / \mathrm{N} 1$ to saturation against the cell lines CHP 212 and 126. To determine if the spectrum of binding observed was due to either the reactivity of subpopulations occurring at different frequencies in the lines tested or to uniform quantitative differences, cells with $\mathrm{MI} / \mathrm{N} \mathrm{l}$ antibody bound under saturating conditions were stained with fluorochrome-labeled antimouse Ig and analysed by both fluorescence microscopy and with the fluorescence-activated cell sorter (FACS).

By light microscopy, only approximately $30 \%$ of the cells in the line CHP 100 appeared fluorescent using either a culture supernatant or an ascites preparation of antibody. This heterogeneity was also seen upon FACS analysis of cells, suggesting either quantitative and/or qualitative differences in the expression of antigen occur within this population (Fig. 2). No morphologic differences could be distinguished between fluorescent positive and negative cells within the cell line, and antigenic expression did not significantly change when cells were either growing exponentially or approaching confluency. The other cell lines examined were homogeneous in their staining profiles being either weakly fluorescent positive on all cells or negative as determined by both microscopy and FACS analysis. Thus quantitative differences in antigenic expression seem to occur between the lines CHP 134,126 , and 212. Detection of the binding of $\mathrm{MI} / \mathrm{N} 1$ to these latter neuroblastoma lines by either fluorescence or iodinated goat anti-mouse Ig appears to yield conflicting results with cells being positive for binding in a modified radioimmune assay and yet negative by fluroescence. This presumably reflects the relative sensitivity of the two assays.

The antigen recognised by $\mathrm{MI} / \mathrm{N} 1$ would appear to show some species specificity because no binding to the mouse neuroblastoma line ICRF N.1. (a clone of C-1300) could be detected under conditions where strong binding to the human line CHP I00 was

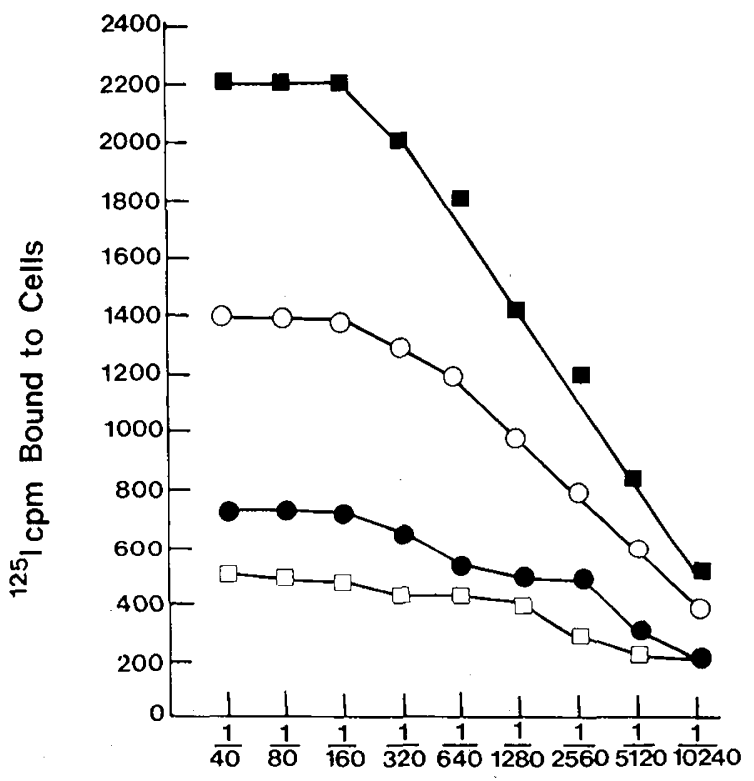

Titre of Ascites Preparation

Fig. I. The binding of monoclonal antibody MI/N1 to different human neuroblastoma cell lines. Two $\times 10^{5}$ cells of each line were incubated with differing dilutions of $\mathrm{MI} / \mathrm{N} 1$ followed by $100,000 \mathrm{cpm}$ of ${ }^{125} \mathrm{I}$-goat antimouse as described in Materials and Methods. $\mathbf{\square}$, binding to CHP 100 $\bigcirc$, binding to CHP $134 ;$, binding to CHP 212; $\square$, binding to CHP 126 . 

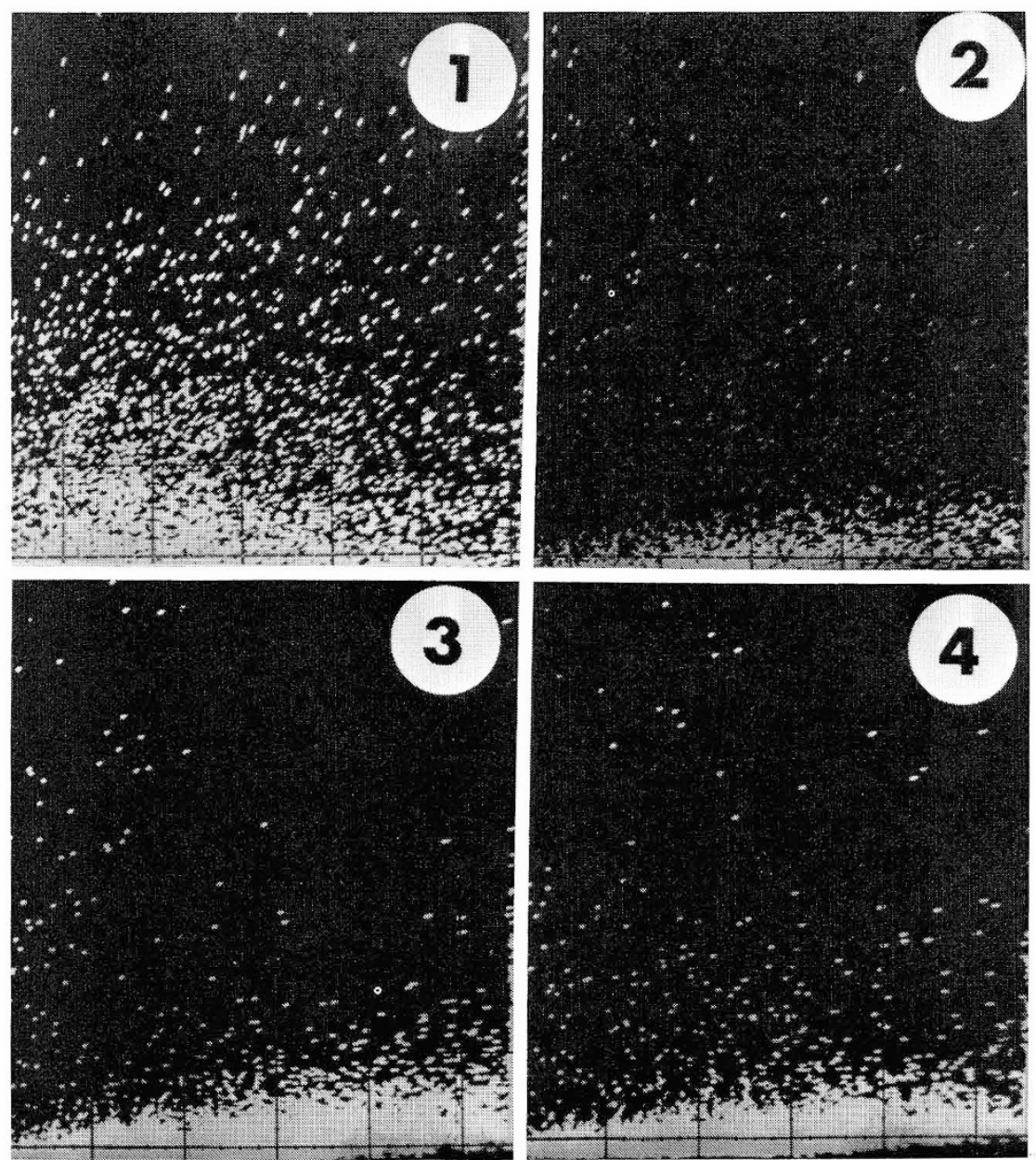

Fig. 2. Heterogeneity in the binding of $\mathrm{MI} / \mathrm{N} 1$ to different human neuroblastoma cell lines as determined by FACS analysis. Ordinate, relative immunofluorescence intensity; abscissa, relative cell size. Cells $\left(10^{6}\right)$ of each line (CHP 100 and $\left.\mathrm{CHP} 212\right)$ were incubated with $\mathrm{MI} / \mathrm{Nl}(1 / 100)$ for 30 min at $4^{\circ} \mathrm{C}$ and, following washing, for an equivalent time with fluroescein conjugated $F\left(a b^{\prime}\right)_{2}$ goat anti-mouse $F\left(a b^{\prime}\right)_{2}$. Cells were analysed for fluorescence using microscopy and the cell sorter and compared with control cultures incubated with the second antibody only. 1 , CHP 100 cell line incubated with MI/NI-FACS profile; by fluorescence microscopy $30 \%$ of cells were positive; 2, CHP 100 cell line control culture-FACS profile; by fluorescent microscopy cells were all negative; $3, \mathrm{CHP} 212$ cell line incubated with MI/N1-by fluorescent microscopy all cells were negative; 4 , CHP 212 cell line-control culture; by fluorescent microscopy all cells were negative.

found (Fig. 3). Furthermore, MI/Nl does not react with the human astrocytoma line UCH-P45, suggesting that the antigen is restricted to neuronal rather than neuroglial cells (Table 1).

\section{REACTIVITY WITH FRESH NEURAL TISSUE}

To ascertain if $\mathrm{MI} / \mathrm{N} 1$ reacts with either human foetal or adult brain, aliquots of an ascites preparation of the antibody were absorbed with equivalent amounts of these tissues. As a control for nonspecific absorption onto brain tissue, a similar incubation of antibody with rat brain was undertaken. The absorbed antisera were subsequently tested for residual binding activity with line CHP 100. The titration curves obtained (Fig. 4) show a single absorption with human foetal brain removed approximately $25 \%$ of the antibody activity whereas adult brain (cerebellum) absorbed $75 \%$ of the reactivity to CHP 100 . MI/NI did not react with adult rat brain because the titration curve obtained with this material was identical to that found for the unabsorbed antibody (Fig. 4).

$\mathrm{MI} / \mathrm{NI}$ reacted (by indirect immunofluorescence) with five of eight bone marrow biopsies heavily infiltrated with neuroblastoma cells; this result possibly reflects the heterogeneity seen in the binding of antibody to neuroblastoma cell lines. An ascites preparation from a child histologically shown to contain neuroblasts also reacted with the $\mathrm{MI} / \mathrm{NI}$, but the one retinoblastoma examined to date did not bind the antibody.

\section{REACTIVITY WITH HAEMOPOIETIC CELLS}

Inasmuch as one objective of producing a monoclonal antibody to neuroblastoma cells was to provide an immunodiagnostic aid for the detection of early metastatic spread in the bone marrow, it was clearly of some importance to examine critically the possible reactivity of $\mathrm{MI} / \mathrm{NI}$ with haemopoietic cells. That some reactivity to haemopoietic cells might be expected is indicated from the binding of the antibody to the cell lines, strongly to the myeloid line HL 60 and weakly to the T-cell leukaemia line HPB-TALL (Table 1). The monoclonal antibody, however, does not react with fresh human red blood cells.

A portion of the cells in normal bone marrow react by indirect immunofluorescence with $\mathrm{MI} / \mathrm{Nl}$. When these were separated by FACS, it was evident that the cells were of the myeloid lineage at different stages of maturation. Lymphocytes and erythroid cells were found in the fluorescent negative fraction. Further separation by FACS of the fluorescent-positive granulocyte population showed that the brightest fraction of cells contained predominantly the most mature cells (neutrophils) (Table 2). Analysis of fractions of decreasingly fluorescent cell populations indicated that the earlier cells in the myeloid lineage expressed less antigen, with the promyelocytes and myelocytes in the dimmest fraction. Normoblastoid cells appeared in the fluorescent-negative population by FACS analysis (see Table 2). 
The above observations are further confirmed by an analysis of leukaemic cells reacting with MI/N1. Although chronic myeloid leukaemias were shown to react with the antibody, the less mature cells found in acxute myeloid leukaemias were unreactive, as were the non-B, non- $\mathrm{T}$ common acute lymphoblastic leukaemias assayed. Of the five T-cell leukaemias examined, only one case was found to contain a population of cells binding $\mathrm{MI} / \mathrm{Nl}$ (paralleling the binding to the line HPB-TALL).

\section{DISCUSSION}

The technique of somatic cell hybridisation has enabled the production of immunologic reagents that are monoclonal and directed against a single determinant; they have, therefore, a much more restricted specificity than most "conventional" polyspecific antisera $(18,19)$. Such reagents should be of considerable use for cell identification in complex or mixed populations, and to this end, an attempt has been made to produce a monoclonal reagent to neuroblastoma cells (12). A monoclonal antibody, MI/NI, is

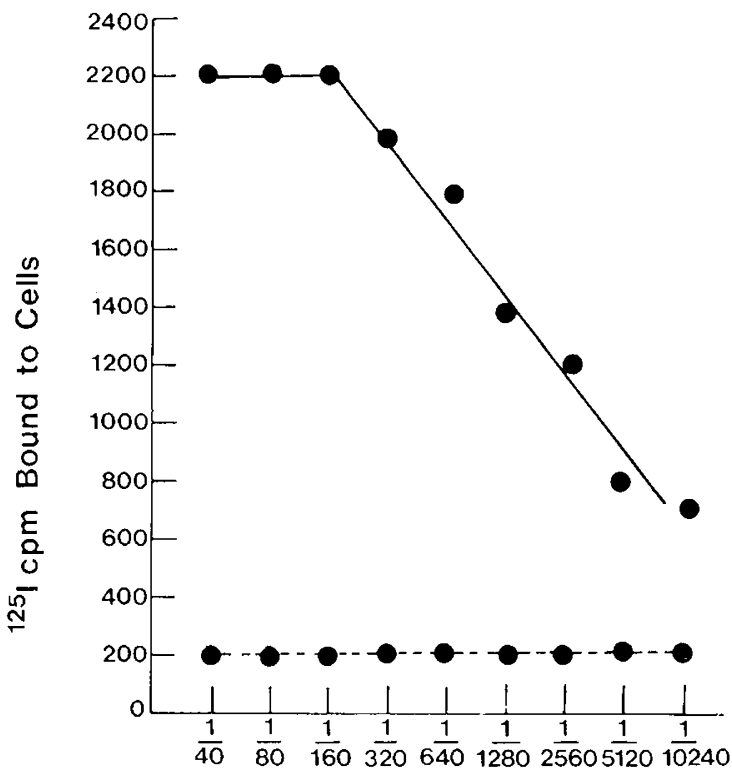

Titre of Antibody

Fig. 3. The binding of $\mathrm{MI} / \mathrm{Nl}$ to human and murine neuroblastoma cells. Two $\times 10^{5}$ cells of each type were incubated with differing dilutions of an ascites preparation of MI/N1 followed by $100,000 \mathrm{cpm}$ of ${ }^{125} \mathrm{I}$-goat anti-mouse (see Materials and Methods). Iodinated antibody bound to the cells is plotted minus a background of $200 \mathrm{cpm}$ obtained by incubating cells with the second antibody only. CHP 100; $--\bullet$, binding to the murine line ICRF N.1. described that reacts with several neuroblastoma cell lines and five of eight bone marrow aspirates heavily infiltrated with neuroblastoma tumour cells.

Quantitative differences in the expression of antigen recognised by $\mathrm{MI} / \mathrm{Nl}$ were observed between the neuroblastoma cell lines

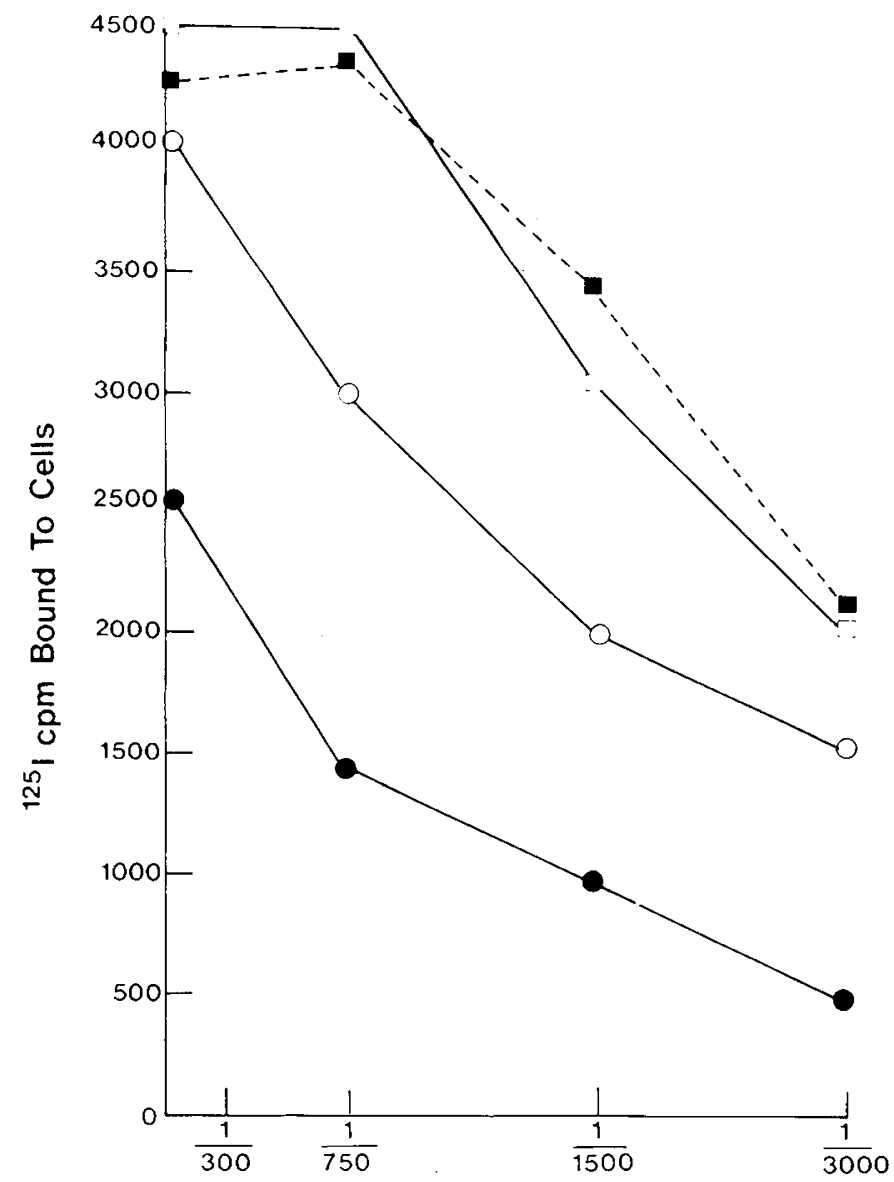

Titre Of Ascites

Fig. 4. The binding of MI/N 1 to $\mathrm{CHP} 100$ neuroblastoma cells after absorption with fresh neural tissue. MI/N1 diluted $1 / 100$ was incubated with freshly prepared neural tissue as described in "Materials and Methods." Different dilutions of this material were subsequently incubated with $2 \times 10^{5} \mathrm{CHP} 100$ cells, followed by $100,000 \mathrm{cpm} .{ }^{125} \mathrm{I}$-goat anti-mouse ("Materials and Methods") iodinated antibody bound to cells is plotted minus a background of $200 \mathrm{cpm}$ obtained by incubating the cells with the second antibody only. - - - , MI/N1 not absorbed; $\square$, absorbed rat foetal brain; $\mathrm{O}$, absorbed human foetal brain ( $16 \mathrm{wk}) ; \mathbf{\square}$, absorbed human adult cerebellum.

Table 2. Analysis of cells binding $M I / N I$ in the bone marrow

Histologic characterisation of cells

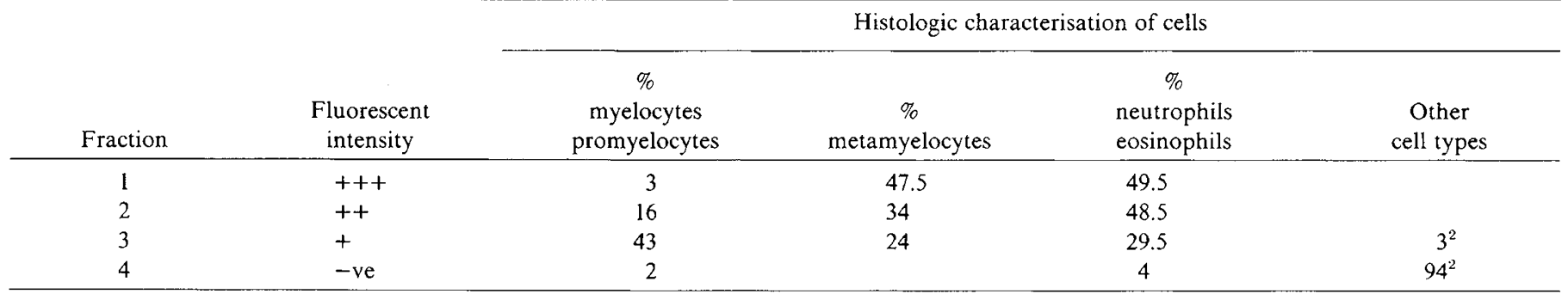

'Red cells were lysed from the bone marrow sample by "flash lysis" using distilled water. The remaining cells $\left(2 \times 10^{7}\right)$ were incubated with $\mathrm{MI} / \mathrm{Nl}$ and fluorescent $\mathrm{F}\left(\mathrm{ab}^{\prime}\right)_{2}$ goat anti-mouse $\mathrm{F}\left(\mathrm{ab}^{\prime}\right)_{2}$ as described in "Material and Methods." After separation by FACS of the populations of cells binding differing amounts of antibody, cytocentrifuge preparations of cells were obtained, and the slides were stained using May-Grunwald Giemsa.

${ }^{2}$ Pronormoblasts, basophilic normoblasts, polychromatic normoblasts, orthochromatic normoblasts, and lymphocytes in the preparation. 
analysed (Fig. 1). One explanation for this observation is that cells in these lines have a maturation arrest at particular levels of neuronal development associated with distinctive antigenic changes ( $c f$. haemopoietic malignancies) $(13,21)$. The expression of antigens or other markers on cell lines may not, however, be a true representation of that found on fresh tissue as the former represent highly selected populations growing only from stage 3 and 4 tumours (10) and may change their antigenic expression under prolonged periods in culture. MI/N1 shows, however, a similar heterogeneity in binding to fresh neuroblasts that have metastasised to the bone marrow. Of eight such marrow aspirates examined, only five appeared positive for MI/NI binding by fluorescent microscopy. A variation in antigenic expression (both quantitative and qualitataive) may thus occur between different neuroblastoma tumours, again possibly reflecting a maturation arrest at different points during neuronal cell differentiation. Differential reactivity of fresh neuroblastoma samples to rabbit anti-neuroblastoma antiserum has been previously described (13). The antigen recognised by $\mathrm{MI} / \mathrm{N} 1$ also appears to be increasingly expressed during foetal brain development (J. T. Kemshead, J. Fitschy, and M. Greaves, manuscript in preparation), further suggesting it may be a differentiation or maturation-linked antigen in neuronal cell development.

Heterogeneity of antigenic expression may exist within a single neuroblastoma cell line (e.g., CHP 100), and this could not be directly linked to cell morphology or cell cycle status. Fractionation (by FACS) and subsequent culture of the fluorescent-positive and -negative cells show that these gradually revert to heterogenous populations of cells (J. T. Kemshead, unpublished observation).

$\mathrm{MI} / \mathrm{N} 1$ does not react with a mouse neuroblastoma cell line or fresh neuronal tissue from either rats or mice, suggesting some species restriction in the expression of antigen. However, because the original immunisations of human neuroblastoma cells were undertaken in mice, nonreactivity to rodent neural tissue provides only equivocal evidence for restricted species expression. Other antibodies against neuroblastoma cells, raised in identical ways do not show such restriction (J. T. Kemshead, unpublished observation).

Biochemical analysis of the antigen is currently under investigation. Binding of antibody to neuroblastoma cells is not inhibited by either pure $\mathrm{GM}_{1}$ or a mixture of glycosphingolipids, suggesting that the antigen is not a ganglioside. This contrasts with the monoclonal antibody described by Eisenbarth et al. (5) which reacts with a ganglioside on neural cell surfaces. Indirect evidence that MI/N1 does not react with highly conserved molecules such as glycolipids also comes from the restricted species reactivity found.

The reactivity of $\mathrm{MI} / \mathrm{Nl}$ with relatively mature myeloid cells may appear to compromise its use in detecting malignant neuroblasts that have metastasised to the bone marrow. This problem may, however, be avoided because reactive myeloid cells are morphologically identifiable and can be counterstained with antimyeloid/granulocyte sera. A more serious limitation may be the heterogeneity of antigenic expression on neuroblastoma cells in vivo, a point currently under investigation. Another monoclonal antibody raised against neuroblastoma cells (PI 153/3) by Kennett and Gilbert (16) also cross-reacts with some haemopoietic cells. Unlike $\mathrm{MI} / \mathrm{N} 1$, this antibody does not react with early cells of the myeloid lineage or with $\mathrm{T}$ cells but reacts with $\mathrm{B}$ cells and their progenitors and corresponding leukaemias (8). MI/N1 has no reactivity with $\mathrm{B}$ cells or their progenitors whereas its reactivity to $T$ cells remains to be fully investigated.

Further attempts are being made to produce a monoclonal antibody with specificity restricted to normal and/or malignant neural cells although in our hands almost all of the antibodies produced show some cross-reactivity with cells of the haemopoietic system.

\section{REFERENCES AND NOTES}

1. Akeson. R., and Seeger, R. C.: Interspecies neural membrane antigens on cultured human and murine neuroblastoma cells. J. Immunol., 118: 1995 (1977).

2. Breslow, N., and McCann, B.: Statistical estimation of prognosis for children with neuroblastoma. Cancer Res., 31: 2098 (1971)

3. Casper, J. T., Borella, L., and Sen, L.: Reactivity of human brain antiserum with neuroblastoma cells and nonreactivity with thymocytes and lymphoblasts. Cancer Res., 37: 1750 (1977).

4. D’Angio, G. J., Evans, A. E., and Koop, C. E.: Special pattern of widespread neuroblastoma with a favourable prognosis. Lancet, $l$ : 1046 (1971).

5. Eisenbarth, G., Walsh, F. S., and Nirenberg, M.: Monoclonal antibody to plasma membrane antigen of neurons. Proc. Natl. Acad. Sci. U. S. A., 76: 4913 (1979)

6. Gitlow, S. E., Dziedzic, L. B., Strauss, L., Greenwood, S. M., and Dziedzic, S. M.: Biochemical and histologic determinants in the prognosis of neuroblastoma. Cancer (Phila), 32: 898 (1973)

7. Greaves, M. F. and Janossy. G.: Patterns of gene expression and cellular origins of human leukaemias. Biochim. Biophys. Acta, 516: 193 (1978).

8. Greaves, M. F.. Verbi, W., Kemshead, J. T., and Kennett, R. H.: A monoclonal antibody identifying a cell surface antigen shared by common acute lymphoblastic leukaemias and B lineage cells. Blood, 56: 1141 (1980).

9. Herzenberg, L. A., and Herzenberg, L. A.: Analysis and separation using the fluorescence activated cell sorter (FACS). In: D. M. Weir: Handbook of Experimental Immunology. Vol. 3, Chap. 22, p. 1. (Blackwell Scientific Publications, Oxford, 1977).

10. Jaffe, N.: Neuroblastoma: review of the literature and an examination of factors contributing to its enigmatic character. Cancer Treat. Rev., 3: 61 (1976).

11. Kearney, J. F., Radbruch, A., Liesegang, B., and Rajewsky, K.: A new mouse myeloma cell line which has lost immunoglobulin expression but permits the construction of antibody secreting hybrid cell lines. J. Immunol., 123: 1548 (1979)

12. Kemshead, J. $\Upsilon$., and Black, J.: Developments in biology and diagnosis of neuroblastoma. In: Developmental Medicine and Child Neurology. William Heinemann Medical Books Ltd. (in press)

13. Kemshead, J. T., Greaves, M., Pritchard, J., and Graham Pole, J.: Differential expression of surface antigens on human neuroblastoma cells. In: A. Evans: Advances in Neuroblastoma Research. pp. 816-829 (Academic Press, Inc. New York, (980)

14. Kemshead, J. T., North, J., and Askonas, B. A.: IgG anti-hapten antibody secretion in vitro commences after extensive precursor proliferation. Immunology, 33: 485 (1977)

15. Kennet, R. H., Doris, K. A., Tung, P. A., and Klinman, N. R.: Hybrid plasmacytoma production: fusions with adult spleen cells, monoclonal spleen frag ments, neonatal spleen cells and human spleen cells. Curr. Top. Microbiol. Immunol., 81: 77 (1978).

16. Kennett, R. H., and Gilbert, F.: Hybrid myelomas producing antibodies against a human neuroblastoma antigen present on fetal brain. Science (Wash., D.C.) 203: 1120 (1979).

17. Kinnier-Wilson, L. M., and Draper, G. J.: Neuroblastoma, its natural history and prognosis: a study of 487 cases. Brit. Med. J., 3: 301 (1974).

18. Köhler, G., and Milstein, C.: Continuous culture of fused cells secreting antibody of predefined specificity. Nature (Lond.), 256: 495 (1975).

19. Köhler, G., and Milstein, C.: Derivation of specific antibody producing tissue culture and tumour lines by cell fusion. Eur. J. Immunol.., 6: 511 (1976).

20. Littlefield, J. W.: Selection of hybrids from matings of fibroblasts in vitro and their presumed recombinants. Science (Wash. D.C.), 145: 709 (1964)

21. Roberts, M., Greaves, M., Janossy, G., Sutherland, R., and Pain, C.: Acute lymphoblastic leukaemia associated antigen. I. Expression in different haematopoietic malignancies. Leukemia Res., 2: 105 (1978).

22. Schlesinger, H. R., Gerson, J. M., Moorhead, P. S., Maquire, H., and Hummeler $\mathrm{K}$.: Establishment and characterisation of human neuroblastoma cell lines. Cancer Res., 36: 3094 (1976)

23. Thierfelder, S., Rodt, R. G., Thiel, E., Hoffman-Fezer, T., Netzel, E., Haas, R. G., Wünvwündsch, G. F., and Binder-Gotze, C.: Immunological markers for classification of leukaemias and non-Hodgkin lymphomas. In: R. Gross, J. Hellridgel: Strategies in Clinical Haematology, pp. 41-48 (Springer-Verlag, Berlin, 1979)

24. The authors would like to thank Dr. M. Parkhouse for the gift of goat anti-mouse immunoglobulin, Dr. P. Beverley for the human astrocytoma cell line, D. Delia and $\mathbf{J}$. Robinson for technical assistance, and $\mathbf{J}$. Riggs for typing the manuscript.

25. Requests for reprints should be addressed to: Dr. J. T. Kemshead, Department of Medical Oncology, St. Bartholomew's Hospital, West Smithfield, London EClA 7BE, England.

26. This research was supported by the Imperial Cancer Research Fund.

27. Received for publication October 7, 1980.

28. Accepted for publication December 12, 1980 